\title{
Menguji Taji Implementasi Kebijakan Pemberian Bantuan Hibah kepada Kelompok Masyarakat di Kabupaten Badung
}

\section{Test the Spurs of Implementation of the Policy for Providing Grant Assistance to Community Groups in Badung Regency}

\author{
Ni Luh Putu Rita Sukmawati* \& I Nyoman Budiana \\ Program Studi Magister Administrasi Publik, Universitas Pendidikan Nasional, Indonesia
}

Diterima: September 2019; Disetujui: Desember 2019; Dipublish: Januari 2020

\section{Abstrak}

Artikel ini bertujuan untuk untuk mengkaji, mendeskripsikan dan menganalisis implementasi kebijakan pemberian bantuan hibah, mengetahui faktor-faktor apa saja yang mempengaruhi kebijakan pemberian bantuan hibah dan mengetahui dampak-dampak yang ditimbulkan dari adanya pemberian bantuan hibah kepada kelompok masyarakat di Kabupaten Badung. Untuk mencapai tujuan tersebut digunakan beberapa metode dan teknik. Metode yang digunakan bertipe penelitian deskriptif kualitatif. Teknik pengumpulan data menggunakan observasi, wawancara dan dokumentasi. Teknik penentuan informan yang digunakan purposif sampling dengan jumlah informan yang telah ditentukan. Kajian ini menyimpulkan bahwa pemberian bantuan hibah kepada kelompok masyarakat di Kabupaten Badung sudah terimplementasi sangat baik sesuai dengan asas keadilan, asas kepatutan, asas rasionalitas, asas transparan, asas akuntabilitas dan asas manfaat untuk masyarakat. Terdapat beberapa faktor yang mempengaruhi kebijakan pemberian bantuan hibah kepada kelompok masyarakat yaitu faktor komunikasi, sumber daya, disposisi dan struktur birokrasi. Kebijakan pemberian bantuan hibah kepada kelompok masyarakat di Kabupaten Badung memilki dua dampak yaitu dampak positif dan negatif. Kedua dampak tersebut tergantung bagaimana kelompok masyarakat Kabupaten Badung menyikapinya.

Kata Kunci: Pemberian Hibah, Kebijakan Publik, Implementasi Kebijakan Public.

\section{Abstract}

This article aims to review, describe and analyze the implementation of the grant aid policy, find out what factors influence the policy of providing grant assistance and find out the effects of providing grant assistance to community groups in Badung Regency. To achieve this goal several methods and techniques are used. The method used is descriptive qualitative research type. Data collection techniques using observation, interviews and documentation. The informant determination technique used was purposive sampling with the number of informants determined. This study concludes that the provision of grant assistance to community groups in Badung Regency has been implemented very well in accordance with the principles of justice, the principle of propriety, the principle of rationality, the principle of transparency, the principle of accountability and the principle of benefits for the community. There are several factors that influence the policy of granting aid to community groups, namely communication, resources, disposition and bureaucratic structure. The policy of providing grant assistance to community groups in Badung Regency has two impacts namely positive and negative impacts. Both impacts depend on how the Badung Regency community groups react to it.

Keywords: Grants, Public Policy, Public Policy Implementation

How to Cite: Sukmawati, N.L.P.R. \& Budiana, I.N. (2020). Menguji Taji Implementasi Kebijakan Pemberian Bantuan Hibah kepada Kelompok Masyarakat di Kabupaten Badung. PERSPEKTIF, 9 (1): 100-110

\footnotetext{
*Corresponding author:

E-mail: niluhputuritasukmawati@gmail.com
}

ISSN 2085-0328 (Print) ISSN 2684-9305 (Online) 


\section{PENDAHULUAN}

Tujuan negara untuk mewujudkan masyarakat adil dan sejahtera tidak hanya menjadi tanggung jawab pemerintah, baik pemerintah pusat maupun pemerintah daerah, tetapi juga menjadi tanggung jawab seluruh komponen masyarakat baik pihak swasta maupun kelembagaan sosial politik yang ada di masyarakat. Kebijakan digunakan untuk memilah dan menunjukkan pilihan terpenting untuk memperkuat kehidupan, baik dalam kehidupan organisasi kepemerintaahan maupun privat. Kebijakan Publik pada umumnya dipahami sebagai salah satu usaha atau aktivitas pemerintah untuk melaksanakan tugas - tugas pemerintahannya, dalam wujud pengaturan ataupun keputusan. Kebijakan Publik merupakan buah dari proses politik yang diupayakan dalam suatu sistem pemerintahan negara, di dalamnya terkandung langkah-langkah yang harus dilaksanakan oleh pemerintah selaku penyelenggara Negara (Sunggono, 1994) (Purwanto \& Sulistyastuti, 2012).

Sebagai wujud tanggung jawab pemerintah dalam memajukan kehidupan bangsa dan negara sesuai dengan UndangUndang Nomor 23 Tahun 2014 tentang Pemerintahan Daerah menyatakan bahwa dalam penyelenggaraan pemerintahan daerah disusun perencanaan pembangunan daerah sebagai satu kesatuan dalam sistem perencanaan pembangunan nasional, perencanan pembangunan daerah tersebut disusun secara berjangka (Theresia, Andii, Nugraha., Prima, Mardikanto, 2014). Pembangunan diartikan sebagai usaha yang dilakukan pemerintah dengan masyarakat secara rutin yang difasilitasi oleh pemerintah menggunakan teknologi terpilih untuk mencapai kesejahteraan masyarakat (Mardikanto, 2009). Sehubungan dengan itu, perlu adanya kekompakan antara para penyelenggara pemerintah di daerah, baik eksekutif maupun legislatif dalam upaya menggali dan memenuhi aspirasi masyarakat untuk mewujudkan program pembangunan di daerah. Pada prinsipnya pembangunan di daerah harus menyentuh seluruh kebutuhan masyarakat guna terwujudnya peningkatan kesejahteraan dalam masyarakat itu sendiri. Peran pemerintah daerah dalam konteks ini adalah sebagai fasilitator dalam mewujudkan hal tersebut. Peran masyarakat yang aktif dalam proses pembangunan merupakan hal yang telah menjadi suatu keniscayaan dalam proses pembangunan itu sendiri.

Pembangunan masyarakat melalui kebijakan pemerintah daerah memiliki kewenangan dalam pemberian bantuan hibah. Salah satu kebijakan Kabupaten Badung tertuang dalam Peraturan Bupati Badung No. 43 Tahun 2018 Tentang Pedoman Pemberian Hibah. Kebijakan tersebut untuk mempercepat proses pembangunan melalui pemberdayaan masyarakat yang salah satunya yang diberikan kepada organisasi masyarakat yang berbadan hukum Indonesia.

Jumlah penetapan penerima hibah dari kelompok masyarakat di Kabupaten Badung Tahun Anggaran 2017 dan Tahun Anggaran 2018.

Tabel 1.1 Jumlah penetapan penerima hibah dari kelompok asyarakat di Kabupaten Badung Tahun Anggaran 2017.

\begin{tabular}{clr}
\hline No & Kecamatan & $\begin{array}{c}\text { Jumlah Penetapan } \\
\text { Penerima Hibah Kepada } \\
\text { Kelompok Masyarakat }\end{array}$ \\
\hline 1 & Kec. Petang & 140 Kelompok Masyarakat \\
2 & Kec. Abiansemal & 477 Kelompok Masyarakat \\
3 & Kec. Mengwi & 719 Kelompok Masyarakat \\
4 & Kec. Kuta Utara & 212 Kelompok Masyarakat \\
5 & Kec. Kuta & 66 Kelompok Masyarakat \\
6 & Kec. Kuta Selatan & 275 Kelompok Masyarakat \\
\hline
\end{tabular}

Sumber: Lampiran Keputusan Bupati Badung Nomor: 5329 / 03 / HK / 2017 Tanggal: 28 Agustus 2017 Tentang: Penetapan Penerima Hibah pada Perubahan Anggaran Pendapatan Belanja Daerah Kabupaten Badung Tahun Anggaran 2017, data diolah. 
Tabel 1.2 Jumlah penetapan penerima hibah dari kelompok masyarakat di Kabupaten Badung Tahun Anggaran 2018, data diolah.

\begin{tabular}{|c|c|c|}
\hline \multirow[b]{2}{*}{ No } & \multirow[b]{2}{*}{ Kecamatan } & \multirow{2}{*}{$\begin{array}{l}\text { Jumlah Penetapan } \\
\text { Penerima Hibah Kepada } \\
\text { Kelompok Masyarakat }\end{array}$} \\
\hline & & \\
\hline 1 & Kec. Petang & 203 Kelompok Masyarakat \\
\hline 2 & $\begin{array}{l}\text { Kec. } \\
\text { Abiansemal }\end{array}$ & 977 Kelompok Masyarakat \\
\hline 3 & Kec. Mengwi & 960 Kelompok Masyarakat \\
\hline 4 & $\begin{array}{l}\text { Kec. } \quad \text { Kuta } \\
\text { Utara }\end{array}$ & 421 Kelompok Masyarakat \\
\hline 5 & Kec. Kuta & 162 Kelompok Masyarakat \\
\hline 6 & $\begin{array}{l}\text { Kec. Kuta } \\
\text { Selatan }\end{array}$ & 425 Kelompok Masyarakat \\
\hline
\end{tabular}

Sumber: Lampiran Keputusan Bupati Badung Nomor: 124 / 054 / HK / 2018 Tanggal: 30 Agustus 2018 Tentang: Penetapan Penerima Hibah pada Perubahan Anggaran Pendapatan Belanja Daerah Kabupaten Badung Tahun Anggaran 2018, data diolah

Berdasarkan tabel di atas, Tahun Anggaran 2017 dan Tahun Anggaran 2018 mengalami perubahan pada penerima hibah hal ini dikarenakan alokasi anggaran untuk dana hibah setiap tahunnya berbeda sesuai kebutuhan untuk meningkatkan kesejahteraan masyarakat. Adapun alokasi dan jumlah dana hibah dari pemerintah daerah adalah sebagai berikut: a) Pada tahun 2017, alokasi anggaran belanja hibah sebesar: Rp.525.248.881.222; b) Pada tahun 2018, alokasi anggaran belanja hibah sebesar: Rp.714.093.052.410

Implementasi pemberian bantuan hibah kepada kelompok masyarakat memiliki beberapa masalah yang sering terjadi, di antaranya adalah kelemahan dalam perencanaan proposal, pertanggungjawaban dari penggunaan dana hibah yang masih banyak fiktif, penyaluran yang tidak prioritas, anggaran hibah yang diajukan tidak rasional, dan penerima yang tidak jelas dan tepat sasaran (Sinulingga, Nasution. \& Batubara, 2018) (Nasution \& Husni, 2016); (Zulkarnaen, 2011); (Lubis, 2012); (Yuda \& Purnomo, 2018). Terkait dengan permasalahan tersebut diperlukan adanya pengkajian kebijakan pemberian bantuan hibah kepada kelompok masyarakat
(Wahab, 2012). Pengkajian tersebut dilakukan untuk mengetahui apakah kebijakan pemberian bantuan dana hibah sudah terealisasikan sesuai peraturan dan asas yang dijadikan pedoman yaitu asas kepatutan, rasionalitas, keadilan, dan manfaat untuk masyarakat, serta tujuan untuk mempercepat pertumbuhan pembangunan, meningkatkan kesejahteraan masyarakat dan pemberdayaan masyarakat di Kabupaten Badung apakah sudah tercapai atau tidak.

Alokasi anggaran hibah yang diberikan oleh Pemerintah Kabupaten Badung yang berjumlah sangat besar akan memiliki beberapa dampak positif maupun negatif serta faktor-faktor yang mempengaruhi Kebijakan Pemberian Bantuan Hibah kepada Kelompok Masyarakat di Kabupaten Badung. Keberhasilan suatu implementasi kebijakan harus dilaksanakan secara nyata dengan berpedoman pada aturan yang mengatur. Implementasi kebijakan pemberian bantuan hibah kepada kelompok masyarakat di Kabupaten Badung pada kenyataannya masih terjadi permasalahan dan kekurangan dalam proses realisasinya.

Melihat permasalahan serta faktafakta yang terjadi di lapangan penulis tertarik untuk melakukan penelitian lebih dalam dengan mengambil judul "Menguji Taji Implementasi Kebijakan Pemberian Bantuan Hibah kepada Kelompok Masyarakat di Kabupaten Badung". Tujuan dari penelitian ini adalah untuk mengkaji, mendeskripsikan dan menganalisis implementasi kebijakan pemberian bantuan hibah kepada kelompok masyarakat di Kabupaten Badung, untuk mengetahui faktor-faktor apa saja yang mempengaruhi kebijakan pemberian bantuan hibah dan untuk mengetahui dampak-dampak yang ditimbulkan dari adanya pemberian bantuan hibah kepada kelompok masyarakat di Kabupaten Badung. 


\section{METODE PENELITIAN}

Penelitian ini memilih lokasi di Kabupaten Badung, yaitu di lingkungan Pemerintah Kabupaten Badung di Bagian Kesejahteraan Rakyat Sekretariat Daerah Pemerintah Kabupaten Badung Jalan Raya Sempidi, Mengwi, Kabupaten Badung. Terkait dengan pemberian hibah peneliti mengadakan penelitian di beberapa pura dadia atau dalam bentuk pura kahyangan jagat di Kecamatan Abiansemal. Desain penelitian yang digunakan dalam penelitian ini adalah pendekatan penelitian kualitatif dengan jenis penelitian deskriptif agar dapat menggali informasi yang mendalam mengenai objek yang diteliti.

Terdapat dua sumber data pada penelitian ini yaitu data primer dan data sekunder (Hasan, 2005). Data Primer diperoleh dari responden secara langsung sesuai dengan jumlah yang ditentukan dalam penelitian serta dikumpulkan dari wawancara. Data Sekunder diperoleh melalui buku, catatan, arsip, dokumen dan segala bentuk informasi. Berdasarkan fokus permasalahan dalam penelitian ini, sumber data dalam penelitian ini adalah informan, dokumen dan tempat dan peristiwa. Pertama, informan yang dipilih adalah orang yang menguasai dan memahami tentang masalah penelitian. sehingga dapat memberikan informasi, serta terlibat langsung dalam proses penyusunan dan perumusan kebijakan pemberian bantuan hibah. Kedua, teknik dokumen dipakai untuk memperoleh data melalui dokumen-dokumen tertulis berupa peraturan-peraturan, baik ditingkat pusat maupun pemerintah daerah, laporanlaporan dan arsip-arsip yang relevan dengan kebijakan pemberian bantuan hibah. Ketiga, tempat dan peristiwa diperoleh dengan mengadakan pengamatan terhadap lokasi, fasilitas dan invetaris lainnya yang terlibat atau dilibatkan dalam perumusan kebijakan pemberian bantuan hibah.
Pemilihan informan dilakukan dengan teknik purposif sampling, yaitu memilih informan yang mewakili penelitian (Suyanto, 1995). Informan penelitian dalam penelitian adalah Bagian Kesejahteraan Rakyat Sekretariat Daerah Kabupaten Badung, Kepala Desa di lingkungan Kecamatan Abiansemal, Bendesa di lingkungan Kecamatan Abiansemal, Panitia penerima hibah di lingkungan Kecamatan Abiansemal. Informan tersebut dianggap menguasai permasalahan, memiliki data dan bersedia memberikan data yang benar- benar relevan dan terkait dengan pemberian bantuan hibah kepada kelompok masyarakat di Kabupaten Badung. Teknik pengumpulan data yang digunakan dalam penelitian ini yaitu, wawancara mendalam dan terbuka, observasi pengamatan secara langsung terkait dengan fokus penelitian dan dokumentasi (Moleong, 2009).

Pengumpulan data yang dilakukan dengan cara melihat, mencatat dari sumber-sumber tertulis. Kemudian pemeriksaan keabsahan data dilakukan penulis uji keabsahan data dengan menggunakan teknik triangulasi yang akan digunakan adalah pemeriksaan melalui sumber lainnya (Nazir, 2011). Triangulasi dengan sumber lainnya berarti suatu informasi yang diperoleh dari sumber yang berbeda dibandingkandan dicek kembali balik derajat kepercayaan informasi tersebut (Tohirin, 2012). Sumber-sumber yang peneliti temukan merupakan hasil wawancara peneliti dengan informan kunci kemudian divalidasi dengan studi dokumentasi yang berkaitann dengan penelitian serta hasil pengamatan peneliti di lapangan sehingga kemurnian dan keabsahan data terjamin. Setelah data terkumpul, akan dilakukan analisis data dengan cara reduksi data, display data dan menarik simpulan dan verifikasi

HASIL DAN PEMBAHASAN 


\section{Implementasi Pemberian Hibah di Kabupaten Badung}

Bantuan

Implementasi kebijakan dipandang dalam pengertian yang luas merupakan penetapan undang-undang sebelum tahap proses kebijakan. Implementasi dinilai secara luas mempunyai makna pelaksanaan undang-undang di mana sebagai aktor, organisasi, tata cara dan teknik kerja sama untuk melaksanakan kebijakan dalam upaya untuk meraih tujuan kebijakan atau program-program (Kusumanegara, 2010). Implementasi di sisi lain merupakan gejala yang bertautan sehingga mungkin dapat dipahami sebagai suatu hasil keluaran (output) maupun sebagai suatu dampak (outcome) (Winarno, 2012).

Berdasarkan hasil wawancara dengan para informan dapat diketahui bahwa pada intinya masyarakat Badung sangat terbantu dengan adanya penyaluran bantuan hibah ini. Pengimplementasian pemberian bantuan hibah di Kabupaten Badung terdapat beberapa asas yang menjadi acuan pemberian hibah seperti yang tertuang dalam Pasal 2 Perbup No. 43 Tahun 2018 bahwa pemberian hibah dilakukan dengan memperhatikan asas keadilan, asas kepatutan, asas rasionalitas, asas transparan, asas akuntabilitas dan asas manfaat untuk masyarakat.

Pemberian bantuan hibah sudah berperdoman pada asas keadilan. Asas keadilan berarti setiap kelompok masyarakat yang berdomisili menjadi warga di wilayah Kabupaten Badung berhak untuk dibantu sesuai dengan kebutuhan yang layak dan diberi bantuan dengan dana hibah. Peruntukan dana hibah tersebut juga tidak lepas untuk mendukung sasaran program dan kegiatan Pemerintah Daerah seperti contoh pelestarian kebudayaan, fasilitas umum kemasyarakatan (pembangunan balai banjar), kegiatan upacara adat dan lain sebagainya. Pelaksanaan dana hibah tidak boleh diberikan secara berturut- turut pada setiap Tahun Anggaran kepada penerima hibah yang sama. Calon penerima hibah harus mengajukan proposal hibah yang melampirkan surat pernyataan tidak menerima hibah secara terus menerus.

Hal ini menunjukkan bahwa pemberian dana hibah dilakukan secara merata dan memberikan kesempatan kepada penerima hibah yang berbeda setiap Tahun Anggaran. Sehingga nantinya penyaluran dana hibah merata kepada masyarakat dan dapat mendorong masyarakat untuk ikut berperan dalam mendukung kebijakan yang ditetapkan oleh Pemerintah Kabupaten Badung. Sosialisasi kepada masyarakat terkait adanya kebijakan pemberian hibah sesuai dengan peraturan pemberian hibah dapat menambah pemahaman masyarakat dan mendukung kebijakan tersebut.

Pengamalan asas kepatutan dalam pengimplementasian pemberian dana hibah sudah diterapkan dengan baik. Terlihat dari proses awal pengajuan proposal dana hibah yang diajukan oleh kelompok masyarakat akan ditinjau lebih lanjut oleh Perangkat Daerah yang terkait dalam proposal. Kemudian adanya proses monitoring untuk memastikan kebenaran peruntukkan dari penggunaan dana hibah yang akan direalisasikan. Sehingga dana hibah yang terealisasi tersebut digunakan secara tepat dan sesuai dengan aturan serta tidak lepas dalam menunjang program dan kegiatan pemerintah Daerah.

Pengamalan asas rasionalitas terlihat dari kesesuaian penggunaan anggaran dana hibah yang direalisasikan dengan pelaporan pertanggungjawaban yang dilaporkan oleh penerima bantuan hibah. Anggaran bantuan hibah yang direalisasikan tidak sepenuhnya dibantu sesuai dengan Rancangan Anggaran Biaya (RAB) yang terdapat dalam proposal dikarenakan proposal yang diajukan tersebut terlebih dahulu dievaluasi oleh Perangkat Daerah. Evaluasi yang dilakukan untuk menyesuaikan anggaran dalam 
proposal dengan standar harga yang dimiliki Pemerintah Kabupaten Badung untuk penggunaan dana yang akan direalisasikan. Apabila telah terjadi kesesuaian standar harga yang telah ditetapkan di Pemerintah Kabupaten Badung dengan Rancangan Anggaran Biaya (RAB) di dalam proposal hibah maka dapat dipastikan tingkat rasionalitas penggunaan dana hibah dengan peruntukkannya di lapangan.

Penerapan e-Hibah Kabupaten Badung ini bertujuan untuk mencapai pengelolaan bantuan hibah secara transparan, normatif dan akuntabel sehingga mewujudkan tata kelola pemerintahan Kabupaten Badung yang Good Governance. Sebelum adanya aplikasi, pengelolaan hibah dilaksanakan secara manual dari perancangan, evaluasi, sampai penetapan bantaun hibah. Aplikasi e-Hibah dalam perancangan hibah bisa meminimalisir kesalahan dokumen awal pengajuan hibah. Pengajuan awal yang terdapat peracancangan hibah dalam bentuk pembangunan ataupun pengadaan, harus terpapar dengan jelas peruntukan lembaga masyarakat mengajukan bantuan hibah. Setelah melalui pemeriksaan peruntukan pengajuan awal yang benar, akan memudahkan pemerintah untuk melakukan evaluasi dokumen pengajuan hibah. Apabila terjadi kesalahan dokumen, bisa segera diperbaiki oleh kelompok masyarakat penerima hibah melalui aplikasi e-Hibah. Evaluasi dana bantuan hibah yang dilakukan dengan dasar peruntukan hibah. Peruntukan hibah sangat menentukan hasil dari evaluasi proposal. Lembanga masyarakat yang salah menentukan nilai dari Rancangan Anggaran Biaya (RAB) yang tidak sesuai dengan standar harga yang dimiliki oleh pemerintah. Akan mempengaruhi nilai evaluasi bantuan dana hibah secara signifikan. Semua proses evaluasi serta nilai evaluasi dapat dilihat dengan jelas di aplikasi e-Hibah.
Akuntabilitas pengelolaan belanja hibah merupakan satu hal yang vital untuk memberikan kejelasan hukum pelaksanaan dan pertanggungjawaban pembangunan daerah untuk mewujudkan kesejahteraan masyarakat. Pemberian bantuan hibah kepada masyarakat harus terpapar dengan jelas mulai dari peruntukan, maksud dan tujuan bantuan dana hibah. Pemerintah memeriksa kebenaran peruntukan dana hibah dengan cara mengevaluasi proposal pengajuan hibah dari lembaga masyarakat. Nilai evaluasi hibah harus sesuai dengan standar harga biaya yang dimiliki pemerintah. Nilai evaluasi pemerintah diberikan dengan mengunakan prinsip hemat dan efektifitas, sesuai kebutuhan peruntukan lembaga masyarakat.

Kelompok masyarakat sebagai penerima dana hibah dari pemerintah, wajib melaporkan pengunaan dana hibah dengan mengumpul laporan pertangungjawaban. Laporan pertangungjawaban dari lembaga masyarakat sebagai alat bukti pertangungjawaban pemerintah terhadap berjalannya akuntabilitas pengunaan Anggaran Pendapatan Belanja Daerah (APBD).

Asas manfaat untuk masyarakat, sangat jelas terlihat bahwa manfaat yang diberikan dari pemberian dana hibah yang dilakukan oleh Pemerintah Kabupaten Badung membantu meringankan beban masyarakat. Tujuan diberikannya bantuan dana hibah kepada masyarakat adalah untuk memotivasi masyarakat agar turut berperan dan berpartisipasi dalam menunjang program dan kegiatan pemerintah daerah Salah satu contohnya, seperti pelestarian kebudayaan, upacara adat, pembangunan sarana dan prasarana desa dan lainsebagainya yang mendukung terselenggaranya fungsi pemerintahan, pembangunan, dan kemasyarakatan. 
Faktor-faktor yang mempengaruhi Kebijakan Pemberian Bantuan Hibah kepada Kelompok Masyarakat di Kabupaten Badung

Implementasi kebijakan tidak selamanya berhasil, beberapa faktor yang menjadi pengaruh suatu implementasi kebijakan. Hal ini dikarenakan pada umumnya implementasi kebijakan tidak selalu berada pada tempat yang dinamis, sehingga terdapat beberapa macam faktor disekelilingnya yang menjadi pengaruh implementasi kebijakan. Menurut Edward III dalam Widodo (2009) mengemukakan empat faktor yang memiliki peran penting dalam pencapaian keberhasilan implementasi. Beberapa factor yang mempengaruhi keberhasilan atau kegagalan implementasi kebijakan yaitu faktor communication, resources, disposition dan bureucratic structure.

Komunikasi yang dilakukan dalam implementasi kebijkan pemberian bantuan hibah di Kabupaten Badung tergolong belum berjalan dengan efektif, hal ini ditunjukkan dari kurangnya sosialisasi kebijakan. Ini tidak sesuai dengan teori yang dikemukakan oleh Widodo (2009) bahwa informasi perlu disampaikan kepada pelaku kebijakan agar pelaku kebijakan dapat menguasai apa yang menjadi isi, tujuan, arah, dan kelompok sasaran kebijakan. Hal ini dapat membuat pelaku kebijakan untuk menyiapkan halhal apa yang berkaitan dengan pelaksana kebijakan, sehingga proses implementasi kebijakan bisa berjalan efektif serta selaras dengan tujuan kebijakan itu sendiri.

Berdasarkan hasil wawancara yang dilakukan peneliti, beberapa informan mengatakan bahwa sosialisasi yang diterima masyarakat mengenai dana bantuan hibah ini didapat dari mulut ke mulut. Jadi, masyarakat lebih banyak mendapatkan informasi atau sosialisasi dari anggota dewan sebagai perpanjangan tangan dari pemerintah. Sosialisasi oleh anggota dewan dilaksanakan pada waktu reses yaitu dalam proses penyerapan aspirasi masyarakat. Pada saat melakukan penyerapan aspirasi tersebut anggota dewan akan mensosialisasikan terkait dengan adanya bantuan dana hibah yang dilakukan oleh Pemerintah Kabupaten Badung sesuai dengan kebijakan pemberian hibah. Anggota dewan akan menyerap aspirasi masyarakat tersebut dan akan memfasilitasi bantuan hibah kepada kelompok masyarakat yang dapat dibantu dengan diberikan dana hibah.

Pendapat yang dikemukakan oleh Edward III (1980), bahwa komunikasi merupakan syarat utama dalam keberhasilan implementasi kebijakan publik. Menurut Edward III komunikasi ini dibagi lagi menjadi tiga dimensi yaittu dimensi transmission (Transmisi / pemindahan / penyebaran informasi), dimensi clarity (kejelasan) dan dimensi consistency (kekonsistenan). Dimensi tranmisi menharapkan agar kebijakan publik tersampaikan tidak hanya kepada pelaksana (implementors) kebijakan tetapi juga tersampaikan kepada kelompok sasaran kebijakan dan pihak lain yang memiliki kepentingan baik secara langsung maupun tidak langsung. Dimensi kejelasan mengharapkan agar kebijakan yang ditrasmisikan kepada pelaksana, target grup dan pihak lain yang berkepentingan dengan jelas sehingga diantara mereka memahami apa yang menjadi maksud, tujuan, sasaran serta substansi dari kebijakan publik tersebut, sehingga dapat memahami apa yang harus dipersiapkan serta dilaksanakan untuk mensukseskan kebijakan tersebut secara efektif dan efesien. Dimensi konsistensi diperlukan agar kebijakan yang diambil tidak simpang siur sehingga membingungkan pelaksana kebijakan, target grup dan pihak- pihak yang berkepentingan (Nugroho, 2017).

Berdasarkan hasil penelitian, penulis menyimpulkan bahwa dengan komunikasi yang efektif diantara para imlementator kebijakan dapat meyakinkan atau mampu menghilangkan kesenjangan yang terjadi di antara kebijakan dan implementasinya 
di lapangan sehingga tujuan yang diharapkan dari pemberian bantuan hibah dapat tercapai.

Keberhasilan proses implementasi sangat tergantung pada kemampuan untuk menggunakan sumber daya yang tersedia. Pelaksanaan kebijakan pemberian bantuan hibah pada tingkat Pemerintah Kabupaten melibatkan berbagai komponen. Faktor utama dalam megukur suatu kinerja adalah analisis terhadap perilaku yang diperlukan untuk memperoleh hasil yang telah disepakati, bukan penilaian terhadap kepribadian.

Kinerja harus terukur dan parameternya harus mengarah pada halhal konkret. Hasil kerja seseorang dipengaruhi oleh latar belakang, lingkungan budaya, ketrampilan serta ilmu pengetahuan yang mencakup: 1) Kebijakan menyeluruh yang harus diketahui. 2) Kesesuaian antara pengetahuan, keterampilan dengan tugas yang menjadi tanggung jawabnya. 3) Mengetahui mekanisme kerja serta ketentuan peraturan perundangundangan yang berlaku. 4) Mengetahui bagaimana pelaksanaan pekerjaan yang dilakukan oleh atasan dan diri mereka sebagai bawahannya. 5) Memiliki pengetahuan dan kemampuan serta keistimewaan atasan. 6) Mengerti perasaan orang lain yang berkaitan dengan tugas bersama.

Pernyataan dari Edward III bahwa disposisi atau sikap pelaksana merupakan faktor penting untuk memahami implementasi kebijakan publik. Jika implementasi ingin dilaksanakan secara efektif maka pelaksana tidak hanya tahu apa yang harus dilakukan dan memiliki kemampuan untuk melakukannya. Namun, mereka harus memiliki ambisi untuk melaksanakan kebijakan.

Tingkat keseriusan penanganan pemberian bantuan hibah di Kabupaten Badung sangat didukung oleh semua pihak baik Pemerintah Daerah maupun Pemerintah Desa mengingat kebijakan pemberian bantuan hibah ini memiliki tujuan yang sangat serius demi kemajuan dan kesejahteraan khusunya di Kabupaten Badung. Tahun 2017 dan tahun 2018 kebijakan pemberian hibah di Kabupaten Badung ini diberikan telah banyak kegiatan yang dilaksanakan oleh para penerima hibah. Hasil dari berbagai kegiatan tersebut dapat dinikmati oleh seluruh anggotanya dan untuk kepentingan masyarakat yang lebih luas. Hasil kegiatan hibah di masing-masing penerima hibah dapat berbeda atau bahkan sama, karena kegiatan tersebut ditentukan oleh anggota itu sendiri disesuaikan dengan kebutuhan masingmasing.

Edward III dalam Agustino (2008) memberikan penegasan bahwa sumber daya yang cukup untuk melaksanakan kebijakan eksis dan pelaksana, tahu apa yang harus dikerjakan dan ingin mengerjakannya, implementasi mungkin masih bisa gagal karena kelemahan dalam struktur birokrasi. Standard Operating Prosedurs (SOP) dan melaksanakan fragmentasi dapat mendongkrak kinerja struktur birokrasi.

Standard Operating Prosedurs (SOP) merupakan kegiatan yang mengharuskan para pegawai untuk menjalankan kegiatannya secara rutin sesuai dengan tolak ukur yang telah ditetapkan. Pada pemberian hibah ini bagian yang melaksanakan tugas dan fungsi terkait dengan pemberian hibah adalah Bagian Kesejahteraan Rakyat Sekretariat Daerah Kabupaten Badung, di mana bagian kesejahteraan rakyat melaksanakan proses pengusulan hibah yang sudah dilakukan sesuai dengan prosedur yang telah ditetapkan.

Pelaksanaan fragmentasi adalah usaha pengedaran tanggung jawab kegiatan-kegiatan atau aktifitas-aktifitas pegawai di antara beberapa unit kerja. Pelaksanaan fragmentasi dalam kebijakan pemberian bantuan hibah ini, terlihat dari proses evaluasi proposal yang melibatkan 
Organisasi Perangkat Daerah. Organisasi Perangkat Daerah memiliki tugas dan fungsinya masing- masing dalam pelaksanaan realisasi pemberian bantuan hibah yang dilakukan oleh Pemerintah Kabupaten Badung. Melalui pembagian tugas dalam struktur birokrasi, maka pelaksanaan realisasi pemberian dana hibah akan lebih baik karena dilaksanakan oleh setiap unit kerja yang sesuai bidangnya masing-masing.

\section{Dampak Implementasi Kebijakan Pemberian Bantuan Hibah kepada Kelompok Masyarakat di Kabupaten Badung}

Dampak implementasi kebijakan menjadi salah satu bagian penting dalam menilai kinerja kebijakan yang dilakukan Pemerintah Kabupaten Badung terkait pemberian bantuan hibah ini. Hal yang diutamakan adalah setiap kebijakan secara ideal harus memberikan manfaat secara langsung maupun secara tidak langsung kepada masyarakat serta harus sesusai dengan keinginan masyarakat (public), sehingga kebijakan dapat diartikan sebagai kebijakan publik. Menurut Dye (1981), Anderson (1984) dalam Soetari (2014) terdapat beberapa dampak kebijakan yang perlu diperhatikan dalam evaluasi kebijakan, antara lain sebagai berikut (1) Dampak kebijakan terhadap situasi atau kelompok target; (2) Dampak kebijakan terhadap situasi atau kelompok lain selain situasi kelompok target; (3) Dampak kebijakan terhadap kondisi sekarang dan kondisi masa yang akan datang. Berdasarkan penjelasan tersebut maka dapat disimpulkan bahwa sebuah kebijakan yang baik atau buruk dinilai dari sejauh mana perubahan yang dirasakan masyarakat nantinya. Perubahan yang dimaksud tentunya terdiri dari beberapa indikator, terutama indikator pencapaian tujuan kebijakan, efisiensi kebijakan, efektivitas kebijakan tersebut dan outcome kebijakan.
Pemberian dana hibah yang diberikan oleh Pemerintah Kabupaten Badung benar-benar dipergunakan kelompok masyarakat dengan maksimal. Dampak kebijakan pemberian bantuan hibah dari segi sosial ekonomi sangat membantu meringankan beban masyarakat, selain itu juga mampu menghemat biaya yang seharusnya menjadi pengeluaran masyarakat. Penghematan biaya tersebut dapat digunakan oleh masyarakat untuk tambahan kebutuhan biaya modal usaha, konsumsi, biaya pendidikian serta kesehatan. Selain membawa dampak positif, pemberian bantuan hibah kepada kelompok masyarakat oleh Pemerintah Kabupaten Badung tidak lepas dari sisi negatif.

Sisi negatifnya adalah ada kecenderungan pudar atau hilangnya nilai historis artefak atau monumen yang bersejarah dan mengandung nilai kepurbakalaan, serta terjadinya degradasi nilai estetis (hiasan ukiran, warna bahan) dan degradasi nilai filosofis-religius monumen atau bangunan. Hal ini dikarenakan adanya kemudahan untuk mendapatkan bantuan hibah, yang memotivasi masyarakat untuk berlombalomba mengajukan proposal. Pengajuan proposal dilakukan untuk membuat bangunan baru tanpa memikirkan nilai nilai sejarah yang terdapat dalam bangunan tersebut. Khususnya untuk warisan budaya yang mengandung nilai sejarah dan kepurbakalaan hal ini merupakan suatu ancaman yang membahayakan dalam konteks pembangunan karakter bangsa.

\section{SIMPULAN}

Pemberian bantuan hibah kepada kelompok masyarakat di Kabupaten Badung sudah terimplementasi sangat baik sesuai dengan asas keadilan, asas kepatutan, asas rasionalitas, asas transparan, asas akuntabilitas dan asas manfaat untuk masyarakat. Pemberian 
bantuan hibah diberikan kepada kelompok masyarakat yang usulan atau proposalnya telah dipandang layak. Pelaksanaan kebijakan pemberian bantuan hibah yang dilakukan oleh Pemerintah Kabupaten Badung dipandang mampu untuk memotivasi masyarakat, meningkatkan kemampuan masyarakat dan mampu memberdayakan masyarakat karena mampu memberikan fasilitasi untuk merangsang kemandirian masyarakat dalam melaksanakan pembangunan.

Sejumlah faktor yang dipandang mempengaruhi implementasi kebijakan pemberian bantuan hibah kepada kelompok masyarakat di Kabupaten Badung adalah faktor komunikasi, sumber daya, disposisi dan struktur birokrasi. Faktor komunikasi dan sumber daya belum berjalan efektif karena terbatasanya informasi yang diterima oleh masyarakat mengenai pemberian bantuan hibah di Kabupaten Badung khususnya di Kecamatan Abiansemal didapat dari Badan Legislatif dalam hal ini Anggota DPRD. Faktor sumber daya belum berjalan efektif dipengaruhi oleh kurangnya sumber daya manusia yang ada di pedesaan, dan kurangnya pengetahuan dan pengalaman di dalam mengimplementasikan pemberian bantuan hibah.

Pemberian hibah kepada kelompok masyarakat di Kabupaten Badung telah dirasakan memberikan dampak yang positif dalam meningkatkan kesejahteraan masyarakat dengan terwujudnya pelestarian kebudayaan dan fasilitas kemasyarakatan yang memadai. Adanya pemberian bantuan hibah membuat masyarakat termotivasi untuk berlombalomba mengajukan proposal bantuan hibah kepada Pemerintah Kabupaten Badung. Sehingga ini akan berdampak negatif karena masyarakat bisa memanfaatkan dana tersebut untuk membuat bangunan baru tanpa memikirkan nilai-nilai sejarah yang terdapat dalam bangunan tersebut dan masyarakat menganggap semua bisa dilakukan dengan mudah jika sudah mendapatkan bantuan dari pemerintah.

\section{DAFTAR PUSTAKA}

Agustino, L. (2008). Dasar-dasar Kebijakan Publik, Alpabeta.Bandung.

Arikunto, S. (2010). Prosedur Penelitian Suatu Pendekatan Praktik, Rineka Cipta.Jakarta.

BPS Kabupaten Badung. (2018). Kabupaten Badung dalam Angka Badung Regency in Figures 2018. CV. Bhineka Karya.Badung.

Edward, G.C. (1980). Implementing Public Policy. Congressional Quartely Press.USA.

Hasan, E. (2005). Komunikasi Pemerintahan. PT. Refika Aditama, Bandung.

Kusumanegara, S. (2010). Model dan aktor dalam Proses Kebijakan Publik, Grava Media, Yogyakarta

Lubis, E.S., (2012), Implementasi Kebijakan Pemerintah Propinsi Sumatera Utara Dalam Pencegahan Dan Penanggulangan Perdagangan (Trafiking) Perempuan Dan Anak, Jurnal Administrasi Publik (Public Administration Journal), 1 (1): 108-141

Mardikanto, T, (2009). Sistem Penyuluhan Pertanian, UNS Press, Surakarta.

Moleong, L.J, (2009). Metode Penelitian Kualitatif. PT Remaja Rosdakarya, Bandung.

Nasution, C., \& Husni T., (2016). Implementasi Kebijakan Program Pembinaan Dinas Sosial dan Tenaga Kerja Terhadap Gelandangan dan Pengemis di Kota medan, Jurnal Administrasi Publik Universitas Medan Area, 4 (2): 105-119

Nazir, M, (2011). Metode Penelitian. Ghalia Indonesia, Bogor.

Nugroho, R. (2017). Public Policy Dinamika Kebijakan Publik Analisa Kebijakan Publik, Manajemen Politik Kebijakan Publik, Etika Kebijakan Publik, Kimia Kebijakan Publik. PT. Gramedia, Jakarta.

Purwanto, E.A. \& Sulistyastuti, D.R. (2012). Implementasi Kebijakan Publik: Konsep dan Aplikasinya Indonesia. Grava Media, Yogyakarta.

Sinulingga, L.O. Nasution, M.H.T. \& Batubara, B.M. (2018). Implementasi Kebijakan Pajak Progresif Bagi Kendaraan Bermotor. PERSPEKTIF, 7 (1): 19-23

Soetari, E, (2014). Kebiajakan Publik. CV. Pustaka Setia, Bandung.

Sugiyono. (2012). Metode Penelitian Kuantitatif Kualitatif dan R\&D. Alfabeta, Bandung.

Sunggono, B. (1994). Hukum dan Kebijakan Publik. Sinar Grafika, Jakarta

Suyanto, B, (1995). Metode Penelitian Sosial. Airlangga University Press, Surabaya.

Theresia, A., Andi, K.S., Nugraha., Prima G.P., Mardikanto, T. (2014). Pembangunan 
Ni Luh Putu Rita Sukmawati \& I Nyoman Budiana, Menguji Taji Implementasi Kebijakan

Berbasis Masyarakat Acuan Bagi Praktisi, Akademisi, dan Pemerhati Pengembangan Masyarakat. Alfabeta, Bandung.

Tohirin. (2012). Metode Penelitian Kualitatif Dalam Pendidikan dan Bimbingan Konseling.PT Raja Grafindo Persada, Jakarta.

Wahab, S.A. (2012). Analisis Kebijakan Formulasi ke Penyusunan Model-model Implementasi Kebijakna Publik. Bumi Aksara, Jakarta.

Widodo, J. (2009). Analisis Kebijakan Publik: Konsep dan Aplikas Analisis Proses Kebijakan Publik. Cetakan Ketiga, Banyumedia Publishing, Malang.
Winarno, B. (2012). Kebijakan Publik Teori, Proses dan Studi Kasus. CAPS. Yogyakarta.

Yuda, 0.0. \& Purnomo, E.P. (2018). Implementasi Kebijakan Pengendalian Pencemaran Limbah Cair Hotel di Kota Yogyakarta Tahun 2017. Public Admnistration Journal (Administration Public Journal). 8 (2): 163-171.

Zulkarnaen, T.R., (2011), Implementasi Kebijakan Pengawasan Dan Pengendalian Muatan Lebih (Studi Kasus pada Unit Pelaksana Penimbangan Kendaraan Bermotor Dinas Perhubungan Provinsi Sumatera Utara), Jurnal Administrasi Publik (Public Administration Journal), 1 (2): 209-231. 